\title{
Vörn og sókn fyrir heilbrigđisvísindi á Íslandi
}

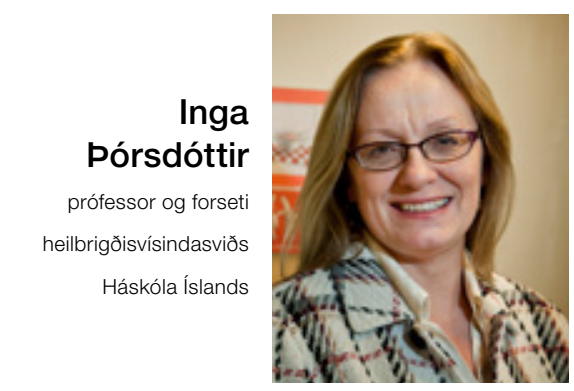

ingathor@hi.is

Heilbrigðisvísindasvið Háskóla Íslands byggistá 6 deildum sem menntað hafa meira en $95 \%$ af faglærðu heilbrigðisstarfsfólki í landinu. Menntun og rannsóknir heilbrigðisgreina fela óhjákvæmilega í sér pátttöku í heilbrigðispjónustu og starfsnám er mikilvægur hluti námsins. Deildir sviðsins eru læknadeild, par sem kennd er læknisfræði, sjúkrapjálfun, geislafræði og lífeindafræði, hjúkrunarfræðideild, lyfjafræðideild, matvæla- og næringarfræðideild, sálfræðideild og tannlæknadeild. Ekki er hægt að kenna læknisfræði eða aðrar greinar heilbrigðisvísinda án pess að leiðbeina nemanda sem æfir sig og kenna í raunverulegu klínísku umhverfi. Innan sviðsins starfar pess vegna fólk sem pjónustar almenning pegar mest á reynir í lífinu, pegar barn fæðist, pegar slys verða og pegar veikindi steðja að. Мiðað við mikilvægi pessarar menntunar kann mörgum að finnast sérkennilegt að fjórar af 6 deildum sviðsins hafi verið reknar með tapi undanfarin ár par sem fjárframlög til peirra eru of lág. Léleg fjárhagsleg staða er einnig ótrúleg pegar horft er til pess að heilbrigðisvísindasvið er pað svið Háskólans sem tengist flestum sprotafyrirtækjum, en nýsköpun á öllum sviðum sem varða heilsu er ein öflugasta vaxtargrein pekkingariðnaðarins. Sprotafyrirtæki sem hafa próast og orðið til innan heilbrigðisvísindasviðs eru meðal annars á sviði læknisfræði, lyfjafræði og sjúkrapjálfunar. Pýðing matvæla- og lyfjaiðnaðar er mikil í útflutningi okkar og pjóðartekjum. Lyfjaiðnaður er til dæmis stærri hluti af hagkerfi Íslendinga en tíðkast í flestum löndum og skilar lyfjaútflutningur um pað bil 3-4\% af útflutningstekjum okkar. Starfið innan heilbrigðisvísindasviðs er atvinnulíf sem felst í kennslu, rannsóknum og nýsköpun heilbrigðisvísinda og er pess vegna órjúfanlegur hluti af íslensku atvinnulífi.

Fjármögnun allra deilda Háskóla Íslands er byggð á mati á árangri í kennslu og rannsóknum. Kennsluárangur miðast við fjölda stúdenta sem preyta próf og árangur í rannsóknum er metinn eftir fjölda birtra greina og tilvitnana í pær, eftir peim styrkjum sem fást úr samkeppnissjóðum, og eftir pví hversu margir meistara- og doktorsnemar ljúka námi. Sé horft til pessa fjármögnunarlíkans er vandi heilbrigðisvísindasviðs aðallega tvenns konar. Í fyrsta lagi getum við ekki fjölgað nemendum sem preyta próf á sama hátt og margar aðrar greinar sem ekki fela í sér klínískt nám eða mikið verklegt nám. Kennsluárangur okkar er pví nokkuð stöðugur en heildarfjöldi nema í Háskóla Íslands vex stöðugt. Fjöldi nemenda við Háskóla Íslands er umfram pað sem greitt er fyrir af stjórnvöldum, sem leiðir til pess að greiðsla vegna kennsluárangurs er of lág. Með pví að hækka reikniflokka fyrir heilbrigðisvísindasvið mætti leiðrétta petta og pá væri unnt að mæta hækkuðum kostnaði vegna viðhalds og uppbyggingar innviða fyrir kennslu og rannsóknir. Í öðru lagi er ósamræmi milli pess hve öflugt rannsókna- og vísindastarf er unnið innan heilbrigðisvísindasviðs, og pess að styrkir til rannsóknanna sem berast inn í skólann eru tiltölulega lágir. Petta skapar pyngra rannsóknarumhverfi, og erfiðleika við að halda við aðstöðu og tækjum og við að sinna langtímarannsóknum. Helsta ástæða pessa er verulegur skortur á hérlendu styrkjafé fyrir heilbrigðisvísindi. Rúmlega helmingur rannsóknasjóðs RANNÍS er ætlaður tækni-, verk- og náttúrufræðirannsóknum svo og allmargir, og par á meðal langstærstu, sérsjóðir hér á landi. Staða íslenskra heilbrigðisvísinda virðist mun verri. Fyrirkomulag samkeppnissjóða í landinu er nú pannig að opinbert fjármagn samkeppnissjóða til rannsókna á sviði heilbrigðisvísinda er sem svarar um fjórðungi eða fimmtungi pess sem veitt er til rannsókna á ofannefndum sviðum. Nauðsynlegt er að til verði sjóður fyrir rannsóknir á sviði heilbrigðisvísinda. Mikilvægi rannsókna er ótvírætt skilyrði gagnreyndrar pekkingar á sviði velferðarog heilbrigðismála.

Раð er einnig augljóst að heilbrigðisvísindi við Háskóla Íslands purfa sameiginlegt húsnæði. Starfsemi sviðsins er nú mjög dreifð, sem er talið kosta landsmenn háar upphæðir vegna hærri rekstrarkostnaðar og ekki síður vegna allra peirra tækifæra sem ætla má að glatist vegna dreifingarinnar. Рað eru tækifæri til pverfaglegrar kennslu, sameiginlegra alpjóðlegra verkefna og rannsókna, nýsköpunar og nýrra leiða við forvarnir, meðferð og umönnun. Раð er pví hagur allra landsmanna að bætt verði úr pessu hið fyrsta eins og áformað er með nýjum Landspítala. Heilbrigðisvísindasvið háskóla um allan heim eru tengd sjúkrahúsum og pað er báðum aðilum nauðsynlegt. Pessi landfræðilega nálægð er hagur allra sem piggja heilbrigðispjónustu. Hún eykur líkur á bestu mögulegu pjónustu spítalans, pjónar nemendum, og par með framtíðarheilbrigðispjónustu, og er að auki pjóðfélaginu hagkvæm.

Til að leysa fjárhagsvanda heilbrigðisvísindasviðs parf að tvinna saman margar leiðir. Allt starf sviðsins byggist á góðu samstarfi við heilbrigðisvísindastéttir í landinu. Pverfaglegt samstarf innan sem utan háskólans og samstarf við Landspítala, auk Heilsugæslunnar, Hjartaverndar, Embættis landlæknis, DeCode, Krabbameinsfélagsins, Matís og fleiri aðila, er meðal annars lykillinn.

Gleđilegt ár

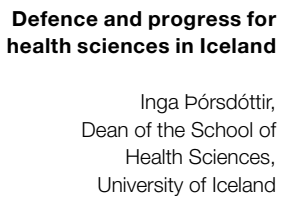

Defence and progress for of the School of University of Iceland 